\title{
The Interface between Linguistic Units and Socio-cultural Frames in Egyptian Arabic: A Cognitive Diglossic Perspective
}

\begin{abstract}
Zakaria K. A. Alssiefy
$\underline{\text { Abstract }}$

The present research addresses the symbiotic relationship that exists between language and culture by investigating the link between linguistic units and socio-cultural frames in Egyptian Arabic ( EA ) from a cognitive, diglossic perspective. The research is based on the assumption that language should be viewed as a representation of the general cognitive processes, rather than a system governed by grammatical rules (Tyler, 2008, p. 459). In other words, the research attempts to explain how linguistic units including proverbs, metaphors, idioms, among other constructions, are reflections of certain socio-cultural frames. The crux of the research is to argue against Sapir -Whorf Hypothesis by demonstrating that such linguistic units are considerably influenced by the way the speakers view and experience the world around them. To this end, a research methodology combining the Cognitive approach, Wierzbicka's (1979) "ethnosyntax" approach, Ferguson's notion of Diglossia, and Malinowski's Context of Situation, is adopted to demonstrate that linguistic units are strongly influenced by socio-cultural frames, and that both are bound up inextricably in various complicated ways. This might provide useful insight into the intimate relationship between linguistic units and socio-cultural frames, and how cultural factors can account for grammatical and semantic change in Egyptian Arabic.
\end{abstract}


The Interface between Linguistic Units and Socio-cultural Frames in Egyptian Arabic: A Cognitive Diglossic Perspective

\section{Key Terms}

Socio-cultural frames - Egyptian Arabic - Cognitive

Linguistics - Ethnosyntax - Diglossia - Sapir-Whorf

Hypothesis

ELLS Vol. No.I (354) December 2016




\section{The Interface between Linguistic Units and Socio-cultural Frames in Egyptian Arabic: A Cognitive Diglossic Perspective}

\section{Introduction}

\section{Zakaria K. A. Alssiefy}

The relationship between language and culture has intrigued, and continues to intrigue, linguists, sociolinguists, cognitive linguists and ethnolinguists alike. As most of what humans internalize in their memories involves abstract concepts, experiences and events, one basic function of communication is represented in the speaker's ability to externalize those internalized concepts, experiences and events to the recipient(s). Language and culture are inextricably bound up with each other in multiple and complex ways, and, therefore, a thorough understanding of language and the way it functions as a means of communication should entail a reasonable awareness of the importance of the influence of the socio-cultural frames on the speakers' selection of specific linguistic units in given socio-cultural contexts.

Although languages possess numerous constructions which compete for expressing a specific meaning or concept in a given situation, the present research attempts, through adopting an eclectic approach combining the Cognitive approach, Wierzbicka's (1979) "ethnosyntax" approach, Ferguson's notion of Diglossia and Malinowski's Context of Situation, to argue against the Sapir-Whorf Hypothesis, in that certain linguistic units including proverbs, metaphors, idioms, among other constructions, are strongly influenced by given socio-cultural frames /settings in Egyptian Arabic ( EA, hereafter). 
The Interface between Linguistic Units and Socio-cultural Frames in Egyptian Arabic: A Cognitive Diglossic Perspective

The principle of situated communication, i.e. communication based on socio-cultural settings / frames, emphasizes the concept of using conventionalized linguistic forms in encoding certain concepts which are embedded within given social, cultural and religious events. As may be observed in many speech communities, certain linguistic constructions displaying specific features are triggered by certain socio-cultural frames /settings, and such linguistic units become so inextricably interconnected with these socio-cultural frames that they become conventionalized within their respective speech communities.

The present research sets out with the notion that the core of Cognitive linguistic research is basically founded upon the attempt to link language forms with the overarching function of language, i.e. communication (Tyler, 2012, p.30). The major assumption is, therefore, that clause structures should be construed not merely as strings of linguistic units governed by a system of grammatical rules, but rather as representations of meaningful contexts in which interlocutors are participating, i.e. this research seeks to accommodate text within context from a cognitive diglossic perspective.

\section{Research Objectives and Rationale}

The major objective of this research is to explore the relationship between language and culture as manifested in the interplay between the speakers' socio-cultural concepts and the linguistic constructions they employ in their everyday interaction in Egyptian Arabic. The research seeks to find satisfactory answers to the following questions:

- How far can socio-cultural frames guide the speaker's pattern of thought towards specific linguistic units in expressing certain concepts, meanings, and ideas? 
- How far can the Sapir-Whorf hypothesis ( language determines one's view of the world ) account for grammatical and semantic variation resulting from the variation in socio-cultural contexts?

- Do structural differences between languages correspond to different cognitive processes?

- To what extent are grammatical constructions sensitive to socio-cultural frames?

- In what way are grammatical units conditioned by socio-cultural frames?

- To what extent may one ( grammar or culture ) embrace the other?

- Which is the real shaper of the other: language or thought?

Although the relationship of language and culture has for long been dealt with by ethnolinguists, sociolinguists, anthropologists, and cognitive linguists, it should be admitted that quite an extensive body of literature has dealt with the controversial issue of "which is more influential on the other: Language or Culture?". Nonetheless, to the best of the researcher's knowledge, serious investigation into the relationship between the linguistic units and socio-cultural frames in Egyptian Arabic within a cognitive diglossic framework has so far been an untrodden field of research. Therefore, the present research claims to be the first to deal with the interface between language and socio-cultural frames in Egyptian Arabic from a cognitive diglossic perspective.

\section{Corpus and Research Methodology}

a- The body of data used in this corpus-based research draws heavily upon a corpus comprising Egyptian 
The Interface between Linguistic Units and Socio-cultural Frames in Egyptian Arabic: A Cognitive Diglossic Perspective

Arabic and Modern Standard Arabic drawn from the files of arabiCorpus which includes natural real-life recordings of Egyptian speech. It is a free, untagged online corpus containing 30 million words with a user-friendly interface maintained by Dilworth Parkinson, professor of Arabic at Brigham Young University. This corpus allows users to find larger structures and grammatical patterns through regular expressions, and other interface features.

b- The varieties of Egyptian Arabic used in this study are Modern Standard Arabic (MSA, hereafter) and Spoken Cairene Arabic (SCA). The former " is the language of written Arabic media, e.g., newspapers, books, journals, street signs, advertisements - all forms of the printed word. It is also the language of public speaking and news broadcasts on radio and television" (Ryding, 2005, p. 5), while the latter represents the more dominant regional form of educated colloquial Egyptian Arabic spoken in Cairo and its immediate adjoining suburbs for purposes of everyday communication. (Diglossic situations will determine the choice of either variety.)

c- Near-spontaneous data has been derived from talkshow programmes conducted in EA. Other supplementary material has been drawn from a number of literary texts written in EA, since the language of such texts is intended to simulate real-life natural conversation. It should be noted that the researcher is a native speaker of this variety, which provides him with the privilege of using his own introspection in the process of collecting and judging the EA data. 
The research adopts a methodology combining the Cognitive approach, Wierzbicka's (1979) "ethnosyntax" approach, Ferguson's notion of Diglossia, and Malinowski's Context of Situation, to find satisfactory answers to the research questions. In addition, the research adopts the concept of culture proposed by Sir Edward Burnett Tylor (2010, para.1) who offers a somewhat simple and straightforward definition of culture which seems to have practical applicability today. He views culture as " that complex whole which includes knowledge, belief, art, morals, law, custom and any other capabilities and habits acquired by man as a member of society."

\section{Theoretical Framework}

\subsection{Cognitive Linguistics}

Cognitive linguistics developed during the 1960s out of the research work of a number of researchers interested in the relationship between language and mind. The crux of this approach has been the relationship between the structure of language and certain cognitive principles which include functional, pragmatic and interactional principles. Most influential among cognitive linguists are Wallace Chafe, Charles Fillmore, George Lakoff, Ronald Langacker, Leonard Talmy and recently Andrea Tyler.

Cognitive linguistics shares the assumption that meaning should be viewed as the most central aspect of language study, and that linguistic units are only vehicles for the expression of meanings. According to Cognitive linguists, linguistic units are closely connected with the semantic structures they are intended to convey, i.e. investigating semantic structures of all meaningful linguistic units is at the heart of their interest. This view came as a direct reaction to 
The Interface between Linguistic Units and Socio-cultural Frames in Egyptian Arabic: A Cognitive Diglossic Perspective

Chomskyan views in which meaning was peripheral to the study of language.

This cognitive approach to language is rooted in the belief that the human mind is always in a constant state of interpreting and reconstructing the world around us into patterns or schemas, i.e. cognitive linguistics is mainly "about language, communication and cognition. Cognition and language create each other. Language has come to represent the world as we know it; it is grounded in our perceptual experience. Language is used to organize, process, and convey information from one person to another, from one embodied mind to another" (Ellis \& Robinson, 2008, p.3).

\subsection{Ethnosyntax}

Wierzbicka (1979) and Langacker (1994) hold that there is a straightforward encoding of culture-specific notions in certain grammatical devices and constructions. Langacker maintains that "quite a number of grammatical phenomena are in one way or another sensitive to cultural expectations" (p.39). He further argues that "direct symbolization of culture-specific conceptions are easily identified in grammatical devices" (ibid., p.44). In the same vein, Enfield (2002, p.3) argues that "Grammar is thick with cultural meaning."

Anna Wierzbicka (1979) who coined the term "ethnosyntax" used it in its 'narrow sense' to claim that it is possible to demonstrate that "every language embodies in its very structure a certain world view, a certain philosophy" ( $\mathrm{p}$. 313). She contends that "grammatical constructions are not semantically arbitrary and their meanings are related to broader cultural understandings" (ibid.p.3). The concept of 


\section{Zakaria K. A. Alssiefy}

"cultural meaning" constitutes the essence of the ethnosyntax approach to language study in its "narrow" sense which focuses on identifying and investigating the "cultural understandings that are embedded in the meanings of particular grammatical structures", but the broader sense of ethnosyntax "studies are concerned with how pragmatic and cultural rules affect the use of grammatical structures" (Gladkova, 2014, p.33).

\subsection{Diglossia}

Research in diglossia has intrigued many sociolinguists since Ferguson's classic work on this notion. The term "diglossia", as used by Charles Ferguson (1959), is defined as:

...a relatively stable language situation in which, in addition to the primary dialect of the language (which may include a standard or regional standards), there is a very divergent, highly codified (often grammatically more complex) superposed variety, the vehicle of a large and respected body of written literature, either of an earlier period or in another speech community, which is learned largely by formal education and is used for most written and formal spoken purposes but is not used by any sector of the community for ordinary conversation. [p.245]

Ferguson was motivated to undertake his remarkable study on the diglossic situations in Egypt and three other countries in reaction to descriptive linguists' strong concern with studying the internal structure of language without providing the most basic information about the "socio-cultural setting 
The Interface between Linguistic Units and Socio-cultural Frames in Egyptian Arabic: A Cognitive Diglossic Perspective in which the language functions" (ibid.,p.249). Specialization was a keyword in distinguishing varieties of language: H (high) variety, the "superposed variety" as used by educated individuals to serve as the standard variety in Cairene Arabic, while L (low) varieties, all other regional varieties, which are used for everyday conversational purposes.

\subsection{Context of Situation}

Bronislaw Malinowski, the father of modern ethnography, conducted his groundbreaking fieldwork study in the domain of cultural anthropology. He coined the notion of "context of situation" and used it in referring to the cultural context in which utterances are used. Following Malinowski (1922), Halliday and Hasan (1985) developed the concept of "context of situation" and defined it as "The environment in which meanings are being exchanged" (p.108). Halliday (1985) and Halliday \& Matthiessen (2004) suggest the following aspects of linguistic significance for any situation: "Field, Mode and Tenor". Hammond et al. (1992, p.2) draw a distinction between the context of culture and context of situation. They contend that the context of situation forms part of context of culture as the latter is used to refer to the meanings and assumptions which are shared by individuals in a speech community, and also subsumes " the culturally evolved expectations of ways of behaving" ( ibid., p.2).

The Sapir-Whorf hypothesis, known as Linguistic Relativity, holds that the way languages are structured determines people's cognition and how they perceive the world around them. In the strong version of this controversial paradigm, Edward Sapir (1929) maintains that the cognitive categories are constrained by linguistic 
categories, while the weak version, which sounds more plausible, holds that language structure and language usage only have an influence on people's perception and actions, which is the essence of the "linguistic relativity principle" ( Whorf, 1956, p. 214).

Sapir views the impact of culture on language as being primarily in the lexicon, and to a lesser degree in the grammar. On the other hand, Whorf (1956) puts forward the notion that "language could influence habitual patterns of thought by emphasizing the connection between language and cognition and introducing the principle of 'linguistic relativity' by which speakers of different grammatical systems are guided by these grammars towards various types of observations, in order to form somewhat different views of the world" (Whorf, 1956: p. 221).

Interest in the Sapir-Whorf hypothesis was renewed in the late 1980s and the late 1990s by research in Cognitive Linguistics. For example, George Lakoff (1993) shows an interest in Whorf's linguistic relativity principle, as he observes that languages contain cultural metaphors resulting from people's metaphorical use of language. These cultural metaphors are supposed to be reflections of the way people think of and perceive the world, hence the use of conceptual metaphors in many languages. As an example, the concept of "time" has been the target of conceptual metaphors in both English and Arabic cultures. Whereas Arabs compare "time" to a weapon (sword), as in: / ?al-waqtu ka-ssayfi / (Lit. Time is like a sword), English natives liken "time" to money (Time is money). This might reflect how people perceive and experience the concept of time in both cultures, which perhaps reveals to what extent the worldview influences language use. 
The Interface between Linguistic Units and Socio-cultural Frames in Egyptian Arabic: A Cognitive Diglossic Perspective

In reaction to the Sapir-Whorf hypothesis, the experimental psychologist Steven Pinker (1995) maintains that "there is no scientific evidence that languages dramatically shape their speakers' ways of thinking" (p.57). He further argues that the linguistic relativity principle, even in its weak version, which asserts that languages merely influence, rather than determine the way individuals view the world around them, is "wrong, all wrong" (ibid.p.57). Goddard and Wierzbicka (1995) argue against Pinker's statement asserting that " it is self-evident to any bilingual that language and patterns of thought are interlinked. On the other hand, it is true that investigations of the relationship between language, culture and cognition have been greatly hindered by conceptual and methodological difficulties" ( $\mathrm{p}$. 39).

\section{Review of Literature}

This section is a review of previous work done on the salient pivots constituting the major concern of this research, namely, the relationship of language and culture, and recent research on diglossia.

\subsection{Culture}

As the concept of "culture" has not been clearly defined, several attempts have been offered to reach a fairly comprehensive and satisfactory definition. Despite the numerous definitions of the term "culture', most of which are either abstract or complex, a comprehensive and satisfactory definition of "culture"; is still lacking, i.e. what culture exactly is and what it actually does, seems to constitute some sort of difficulty. In 1971, British anthropologist Sir Edward Burnett Tylor offered a somewhat 
simple and straightforward definition of culture which seems to have practical applicability today. He viewed culture as “ that complex whole which includes knowledge , belief, art, morals, law, custom and any other capabilities and habits acquired by man as a member of society" ("Sir Edward", 2010, para.1). A definition which sounds complex to some extent, but serves in revealing the real role of culture is offered by Geertz (1973, p.89). She argues that culture is “...a historically transmitted pattern of meaning embodied in symbols, a system of inherited conceptions expressed in symbolic forms by means of which men communicate, perpetuate, and develop their knowledge about and attitudes towards life."

McDaniel, Samovar, \& Porter (2012, p.11) emphasize the symbolic nature of culture as the embodiment of "the rules for living and functioning in society". They argue that "words, gestures and images are merely symbols used to convey meaning. It is our ability to use these symbols that allow us to engage in the many forms of social intercourse used to construct and convey culture" ( ibid., p.11).

Wardhaugh (2006) echoes Goodenough's (1957) wellknown definition of culture, in that culture is "whatever a person must know in order to function in a particular society. ... It is the know-how that a person must possess to get through the task of daily living; only for a few does it require a knowledge of some, or much, music, literature, and the arts " ( p. 221). He believes that his definition echoes the same sense forwarded by Goodenough who contends that "a society's culture consists of whatever it is one has to know or believe in order to operate in a manner acceptable to its members, and to do so in any role that they accept for any one of themselves" ( p. 167). 
The Interface between Linguistic Units and Socio-cultural Frames in Egyptian Arabic: A Cognitive Diglossic Perspective

McDaniel, Samovar, \& Porter (2012, p.13) have also observed that "A common assumption is that people conduct their lives in accordance with how they perceive the world. These perceptions are strongly influenced by culture." Commenting on how culture influences cognitive thinking patterns, they maintain that " thought patterns common to a culture influence the way individuals communicate and interact with each other" (ibid., pp.14-15). They also argue that differences between cultures arise from the different rules used by individuals to play the "game of life" within each culture, or, as they put it: our "own culture rules are ingrained in the subconscious, enabling us to react to familiar situations without thinking. It is when you enter another culture, with different rules, that problems are encountered" ( ibid., p.11).

\subsection{Language and Culture}

The mutual relationship between language and culture has been the target of a fairly large body of systematic research in linguistics and other related interdisciplinary fields. As a start, Boas (1911) denied any relationship between language and culture. He based his argument on a belief that there are people who belong to different cultures but speak languages having different characteristics, for example, Hungarians, Finns, and the Samoyeds of northern Siberia, and that there are also people speaking languages with "very different structures who often share much the same culture, e.g. Germans and Hungarians, or many people in southern India, or the widespread Islamic culture." (Cited in Wardhaugh, 2006, p. 227)

The relationship of language and culture was a major concern of Edward Sapir (1994) and later his student

\begin{tabular}{llll}
\hline \hline ELLS Vol.X No.I (366) December 2016
\end{tabular}


Benjamin Lee Whorf (1956). While Sapir fully acknowledged the inseparable connection between language and culture and that one cannot exist without the other, he strongly held the view that the language habits of a given society have a strong influence on the individuals' view of the world around them. Whorf's view, on the other hand, was that language does not fully determine individuals' worldview, but it has an influential role in determining their worldview. Sapir (1929, p. 207) expressed the relationship between language and culture as follows:

It is quite an illusion to imagine that one adjusts to reality essentially without the use of language and that language is merely an incidental means of solving problems of communication or reflection. The fact of the matter is that the 'real world' is to a large extent unconsciously built up on the language habits of the group. ... We see and hear and otherwise experience very largely as we do because the language habits of our community predispose certain choices of interpretation.

Sapir's ideas were extended by Whorf (1956, pp. 212-13) when he further claimed that:

...the background linguistic system (in other words, the grammar) of each language is not merely a reproducing instrument for voicing ideas but rather is itself the shaper of ideas, the program and guide for the individual's mental activity, for his analysis of impressions, for his synthesis of his mental stock in trade. 
The Interface between Linguistic Units and Socio-cultural Frames in Egyptian Arabic: A Cognitive Diglossic Perspective

Formulation of ideas is not an independent process, strictly rational in the old sense, but is part of a particular grammar, and differs, from slightly to greatly, between different grammars. We dissect nature along lines laid down by our native languages.

Nonetheless, claims of Linguistic Determinism seem to be largely based on observations concerning the lexicon, not the grammar of languages. Those observations have cited data from a number of languages including some primitive varieties. Some of these varieties have several words for different types of entities, others have two different words for the same thing/object. The following evidence is cited in Wardhaugh (2006, p. 227). He mentions that:

Both people and bulls have 'legs' in English, but Spanish requires people to have ' piernas' and bulls have 'patas'. Both people and horses 'eat' in English but in German people 'essen' and horses 'fressen'. Bedwin Arabic has many words for different kinds of camels, just as the Torbiand Islanders of the Pacific have many words for different kinds of yams."

Additionally, such claims are extended to certain grammatical categories, such as number and gender, terms of address, as well as to speech communities providing different distinctions for the colour spectrum. Romaine (1999) outlines this notion as follows: 
No particular language or way of speaking has a privileged view of the world as it "really" is. The world is not simply the way it is, but what we make of it through language. The domains of experience that are important to cultures get grammaticalized into languages ....[and] no two languages are sufficiently similar to be considered as representing the same social reality. [cited in Wardaugh 2006, p. 225]

Echoing Boas (1911), Wardaugh (2006) maintains that "... it is somewhat doubtful that there is any close relationship between the particular types of language, no matter how these are defined, and the cultures of the people who speak them" (p.227). The fact that many people worldwide are bilingual or multilingual in languages displaying different cultures should be taken as counterargument against the linguistic determinism claims. Such language characteristics do not actually seem to constitute a crucial influence on the speaker's worldview. It is, therefore, strongly argued that the socio-cultural aspects prevailing in a speech community have a role to play when it comes to communication among speakers.

\subsection{Recent Research on Diglossia}

This linguistic phenomenon known as diglossia has recently been dealt with by El-Hassan (1978), Badawi (1985), Mitchell (1986), Ryding ( 1990, 1991\&2005), and Elgibali (1993), among other linguists and sociolinguists. Ryding ( 2005) has summarized the diglossic situation in the Arab world as " characterized not simply as a sharp separation between written forms and spoken forms, but as a spectrum or continuum of gradations from "high" (very 
The Interface between Linguistic Units and Socio-cultural Frames in Egyptian Arabic: A Cognitive Diglossic Perspective

literary or formal) to "low" (very colloquial), with several levels of variation in between" ( p.6 ). She further argues that at least two distinct sociolinguistic dimensions characterize these two levels of Arabic in terms of two different functions, or as she puts it:

... first, the social function; that is, the situations in which speakers find themselves - whether those situations are, for example, religious, formal, academic, casual or intimate. Secondly, these levels are conditioned by the educational and regional backgrounds of the speakers. In this intricate interplay of speech norms, situations, and backgrounds, educated native Arabic speakers easily find their way, making spontaneous, subtle linguistic adjustments to suit the dimensions of the occasion and the interlocutors. [ ibid. p. 6]

\section{Analysis and Discussion}

Within every speech community there are a number of situations and contexts, namely socio-cultural, which require interlocutors to employ specific forms of linguistic units ( words, phrases, clauses ) including proverbs, metaphors, idioms, and many other expressions. Such forms are so closely interconnected with relevant socio-cultural frames that they become conventionalized in the cultural memories of their respective speech communities. This interplay between linguistic units and socio-cultural contexts is, to a large extent, manifested in the speakers' daily interaction in Egyptian Arabic. It is strongly argued that socio-cultural meanings and concepts embodied in relevant contexts are

ELLS Vol.X No.I (370) December 2016


assimilated and internalized into the speakers' minds in order to be recalled and externalized in identical situations in the form of linguistic utterances.

This section seeks to analyze a number of typical repetitive linguistic forms used within certain socio-cultural frames in the Egyptian society. Most of these frames recur frequently in social, cultural and religious contexts. However, it should be emphasized that certain socio-cultural frames do not only trigger in the minds of the speakers specific linguistic units, but they also, in given cultural and religious events, entail the use of a specific variety of the same language, i.e. a diglossic situation arises in which the speaker is forced to select between a high $(\mathrm{H})$ or low $(\mathrm{L})$ variety of Arabic. The socio-cultural schemas in the Egyptian community are too numerous to identify, and their strong influence on conceptualizing, processing and externalizing linguistic units will be manifested and analyzed in the following discussion.

\subsection{Socio-cultural influence at the morphology level}

The diminutive forms in EA are perhaps an obvious and relevant example of encoding cultural meanings at the level of morphology. According to Gladkova (2014), the term "diminutive" refers to

a formation of a word that conveys the idea of 'smallness' of the object or quality named, generally, in conjunction with an attitude of intimacy or endearment towards it. This phenomenon is found in many languages, but its scope and exact semantic content vary from language to language (p.34). 
The Interface between Linguistic Units and Socio-cultural Frames in Egyptian Arabic: A Cognitive Diglossic Perspective

\subsubsection{Nouns}

The diminutives of nouns in EA are formed by a change in the medial vowel quality accompanied by gemination, as in: كتاب / kita:b / , كت / kutayyib/ ( book, booklet), or by infixing the long close front vowel between half-close and half-open position /e:/, as in: بحر / baHr / (sea) , / biHe:rah / بحيرة ( lagoon / lake). It is interesting to note that some diminutive forms acquire a change in gender as in بحيرة (noun, fem.), indicating the cultural meaning of smallness.

\begin{tabular}{|c|c|}
\hline noun (mascl. sing.) & diminutive form \\
\hline كتاب $\quad$ book & كتيب \\
\hline sea & lagoon / lake \\
\hline
\end{tabular}
noun (mascl. sing.)

\begin{tabular}{|c|c|}
\hline noun (fem. sing.) & diminutive form \\
\hline novel & novella \\
\hline ضحكه & " little" laugh "أضحوكه \\
\hline girl & بون بنوته $\quad$ girl \\
\hline Hجره & شجيرة \\
\hline لدوله & small state \\
\hline
\end{tabular}

6.1.2. Adjectives

noun (fem. sing.)

\begin{tabular}{|cl|c|}
\hline \multicolumn{2}{|c|}{ adjective (masc. sing.) } & \multicolumn{2}{|c|}{ diminutive form } \\
\hline شطور cute & cutie \\
\hline عسل & honey & a little honey \\
& & \\
\hline
\end{tabular}

adjective (masc. sing.)

\begin{tabular}{|c|c|c|c|}
\hline \multicolumn{2}{|c|}{ adjective (fem. sing.) } & \multicolumn{2}{|c|}{ diminutive form } \\
\hline قمره & beautiful & لقمورة & beautiful \\
\hline عسل & honey & عسولة & honey \\
\hline شاطره & cute & شطورة & cutie \\
\hline بطه & duck & بطوطة & duckling \\
\hline قطه & cat & قطقوطة & kitten \\
\hline
\end{tabular}




\subsubsection{Personal Names}

\section{Adjective (fem. sing.)}

Wierzbicka (1992) has observed that adopting a meaningbased approach to grammar can help unravel the cultural information encoded in the derivative forms of personal names. Personal names in EA exhibit a number of diminutive forms corresponding to some personal names, as follows:

\begin{tabular}{|c|c|c|}
\hline Name (masc.) & \multicolumn{2}{|c|}{ diminutive form } \\
\hline Sameer/ Samer سامر / سمير Sa & سموره & Sammorah \\
\hline محمد /أحمد Mohammad & Hammoudah & حموده \\
\hline Ebraheem & بر هومه & Barhoomah \\
\hline على Ali & عليوه & Eleiwah \\
\hline Omar/ Amr & عموره & Ammorah \\
\hline Hasan & حسونه & Hassonah \\
\hline
\end{tabular}

\section{Diminutive forms of masculine names}

\begin{tabular}{|c|c|}
\hline Name (fem.) & diminutive form \\
\hline ملك $\quad$ Malak & ملوكه Mallookah \\
\hline Amaal / Amal أمل / أمال & Ammoolah \\
\hline Shams & Shammoosah \\
\hline فرحح & Fروحه Farroohah \\
\hline $\begin{array}{c}\text { Eman / Omneyah / Ameenah } \\
\text { / أمينه / أمنيه / إيمان }\end{array}$ & Ammoonah \\
\hline Salma & Salloomah \\
\hline Eishah & عيوشه Ayyu:Jah \\
\hline سحر Sahar & سحوره SaHHoorah \\
\hline سمر Samar & سموره Sammoorah \\
\hline $\begin{array}{c}\text { سوميه / ساميه } \\
\text { Samyah/Somayah }\end{array}$ & سمسمه \\
\hline
\end{tabular}


The Interface between Linguistic Units and Socio-cultural Frames in Egyptian Arabic: A Cognitive Diglossic Perspective

\section{Diminutive forms of feminine names}

It is noteworthy that some "double" diminutives, i.e. reduplicatives, are used to form nicknames consisting of two identical open syllables of one initial consonant and one vowel. They look shorter and more colloquial, such as, فيفى /ولمو / / fi fi /, ميمى / mi mi /, لولو / lu lu /, دودو / du du /, سوسو / su su /, شوشو / لهى جى / Ji Ji /. Such forms are often used among adults to convey a feeling of intimacy, familiarity and endearment, and they are, to a larger degree, associated with talking to and dealing with children for expressing feelings of love, affection and protection. Many of these derivatives are culture-specific, and the speaker's selection among them displays a certain attitude towards the listener.

\subsubsection{Nicknames}

Nicknames are also indicative of cultural meanings expressing intimacy, familiarity, love and endearment, as in these forms: Sameer (Abu- Samrah) ; Mahmoud (AbuHanafy); Ebrahim (Abu-Khali:1); Hisham (Misho); Beshoy/ Bishay ( Bisho); Nabil (Bulbul), and Osman ( Abu Eaffa:n ).

\subsection{Socio-cultural influence at the syntax level}

There are a number of grammatical constructions in EA which are highly sensitive to socio-cultural processes. It has been observed that certain socio-cultural factors have a significant role to play in the variation in the use of certain grammatical constructions. The impersonal construction, the dative ditransitive construction, the passive construction, the imperative construction and the causative construction are among other situationally-conditioned grammatical structures in EA. 


\subsubsection{The Impersonal Construction}

Certain settings in EA may impose on the speaker the use of an impersonal construction which is lacking in a referential subject such as:

الو احد مش قادر يتكلم

/ ?ilwa:Hid mi ? ?a:dir yitkallim /

[ Live conversation]

( Lit. One cannot speak. )

Impersonal constructions, like this, are usually introduced by the impersonal pronoun / ?ilwa:Hid / (one). It is used in contexts expressing the meanings of generalization and denial of personal responsibility. In the utterance:

/ / حد خد فلوس من محفظتى Live conversation]

(Lit. Someone has taken some money from my wallet.)

a father is using a culturally-defined speech act expressing a highly polite accusation in a statement form, in order to avoid using a face-threatening act. Such an utterance is not supposed to accuse a particular person, but it might give an opportunity to any of the listeners to provide a reason for taking this money.

\subsubsection{The Dative Ditransitive Construction}

The dative version of the ditransitive construction in EA involves the use of the preposition / li- / (to / for) before the indirect object to express the dative or the beneficiary function. The speaker's choice of the dative version is influenced by a setting in which the dative / beneficiary object carries more focal significance than the direct object of the clause, as in:

/ ? / idde:t - il- mufta:H li-1-bawwa:b [ Live conversation]

( Lit. I gave the key to the porter). 
The Interface between Linguistic Units and Socio-cultural Frames in Egyptian Arabic: A Cognitive Diglossic Perspective

\subsubsection{The Passive Construction}

Passives in EA are indicative of multifarious meanings. They are preferred to active counterparts when used in relevant settings involving information about the topical focus of the clause, i.e. the end-focus position which is normally occupied by the patient. Focus on the process, knowledge / ignorance of the doer of the action and fearing of / from the doer of the action, and many other pragmatic functions are contextual factors requiring the use of the passive. In the utterance:

/ muba:ylu -il gidi:d -itsara? / [ Live conversation]

(Lit. His new mobile phone was stolen),

the speaker uses a passive form as the context involves emphasis on the act of stealing not on the doer of the action. It should also be noted that a passive verb form, such as /? itsara? / (was stolen), is often confused with other commonly used verbs in CA, known as reflexive verbs denoting " a mediopassive sense of the action involved in the verb" ( Ryding,2005, p.657). Such verbs are prefixed with /it-/ or /in-/, and they occur in other contexts involving / muTa:wakah / (obedience and conformity), as they reflect “ a resultative state of the object” ( ibid.,657), as in: / الباب اتقفل / إنقفل / ?ilba:b -it?afal / -in?afal / ( the door closed). Here, the user of such an utterance is not concerned with the agent or doer of the action as much as with the resultative state of the object (the door). This might give support to the influence of the context on the choice of the grammatical construction.

\subsubsection{The Imperative Construction}

Variation in the structure of the imperative construction may also reflect the 
influence of the socio-cultural factor on the use of language. Among equals, an imperative proper is normally preferred, as in:

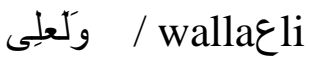

( Lit. Give me a light.)

From superior to inferior, / istanna laHZah /

( Lit. Wait a moment!)

[ Live conversation]

Wording of requests, a common form of the imperative construction, is influenced by certain cultural as well as pragmatic contexts. A number of variants of requests are possible in EA, for example one common variant is

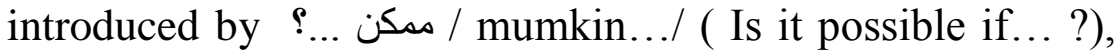
as in: ممكن تولعلى / mumkin tiwallaعli / ( May/can you give me a light?). Requests can be further mitigated by politeness

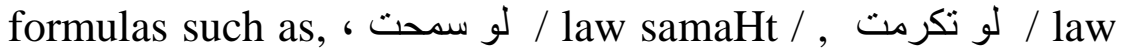
takarramt /, من فضلك / min faDlak / ( please), and بـ / لب / bass / (just, only). They appear either initially or finally in the clause. Yes-no interrogatives introduced by modals such as أقدر / mumkin /andar / ( Can I... ) are used in contexts giving the listener the freedom of agreement, and they show a higher degree of politeness. Additionally, the / interrogative-cum-conditional form such as, فيه مانع لو ....) fi:h ma:niع law.../ ( Is there any objection if...?), تتضايق

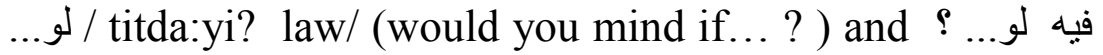
مشكله / fi: mufkilah law / ( would there be any problem if... ?). Other request forms expressing the speaker's gratitude take the following form: أكون مدنون لو... / ?aku:n mamnu:n law / (I'd be grateful if ...) and هاكون متشكر لو / لو / haku:n mutafakkir law / (I'll be thankful if...).

It is also noteworthy that certain imperatives formed of two or three bare infinitives are found in EA. Such forms are 
The Interface between Linguistic Units and Socio-cultural Frames in Egyptian Arabic: A Cognitive Diglossic Perspective

mainly acceptable from superiors to inferiors, and from adults to other family members, as in:

- / ru:Hi dawwari عale:ha / [ TV serial ]

( Lit. Go find it ), [ A housewife to a maidservant ]

- / إنزل اشتري لنا فطار / Inzil -iftri -l-na -fTa:r /

[ TV Promo.]

(Lit. Go buy us some breakfast), [ A father to a son ]

- روح اجرى افتح الباب / 1 ru:H -igri -iftaH -ilba:b /

[ Live conversation]

( Lit. Go, hurry, open the door. ) [ A mother to a daughter ]

\subsubsection{The Causative Construction}

The Causative construction in EA has a very special form, as the information embedded in normal causative structures, in languages such as English, is self-evident from the grammatical structure of the causative clause, namely, ( $\mathrm{HAVE}+\mathrm{N}+\mathrm{PP}$ ), i.e. the syntactic elements can help nonnatives of English to infer causativity through the structure. EA causatives take the form of declaratives, which often causes misunderstanding to natives of other cultures. Examples include the following EA culture-specific forms: / / أنار ايح اصلح العربيه /ana ra:yiH -aSallaH-l-عarabiyyah /

[ Live conversation]

(Lit. I am going to repair the car. ) ( I am going to have the car repaired)

عa:wiz - aHla? Jaعri /

[ Live conversation]

( Lit. I want to cut my hair), (I want to have my hair cut ), and

/ ra:Hit tiSbuy Jaعraha /

[ Live conversation]

ELLS Vol.X No.I (378) December 2016


(Lit. She went to colour/dye her hair), ( She went to have hair coloured / dyed).

The structure of EA causative clauses often causes misunderstanding for natives of other cultures, as it clearly indicates that the subject is the instigator of the action, which is not true.

\subsubsection{The conditional construction}

In the Egyptian community, a speakers' use of a conditional sentence, specifically, if-clause type 2, to express dissatisfaction or regret involves some religious implications, since the use of if, according to the Prophetic Tradition "if opens the work of the devil" إن لو تفتح عمل |

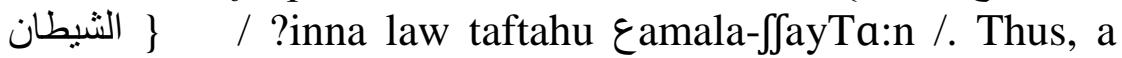
speaker's use of a conditional sentence of this type in a situation, where the speaker expresses his /her dissatisfaction or even rejection of a given unexpected or unfavourable happening, is often commented on by using this prophetic tradition.

\subsection{Noun Phrases}

\section{Greetings, Congratulations and Condolences}

The strong impact of the socio-cultural factor on the speakers' linguistic output/performance is perhaps apparent in the use of the formulas expressing greetings, compliments, congratulations, and condolences, not to mention proverbs, which are all prevalent within the Egyptian society. Such linguistic formulas are so closely linked with their settings / occasions that most of them are fully saturated with the features of such settings. The word صباح/Saba:H/ (morning) in the greeting صباح الخير/Saba:H- il-xe:r / (good morning), and the word مساء /masa:?/ ( evening ) in مساء الخير /masa:?il-xe:r/ (good evening) are, definitely, not used 
The Interface between Linguistic Units and Socio-cultural Frames in Egyptian Arabic: A Cognitive Diglossic Perspective

interchangeably, as each is a part of its respective setting. Syntactically, the noun الخير/?il-xe:r/ occurs with the definite article /?il- /. Likewise, the word / xuTu:bah / (engagement) in the congratulating utterance is prefixed with the definite article /?il-/:

/ mabru:k- il-xuTu:bah/

( Lit. Congratulations on the engagement)

[ Live conversation] and the word /tar?iyyah/ (promotion) in:

/ mabru:k- i-ttar?iyyah/

( Lit. Congratulations on the promotion)

[ Live conversation] cannot be interchanged for the same reason. Syntactically, the nouns occurring after the word /mabru:k/ are preceded by the definite article /?il-/.

Utterances expressing condolences in EA convey a touch of grief and sorrow, and they are used as a means of showing sympathy for someone who has lost a dear person. They fall into two types: the first type belongs to (L) variety as in: / fidd He:lak/ (Lit. Pull yourself together) and /?il-ba?iyya-fHaya:tak/ ( Lit. May Allah grant you a longer life); and the second type uses $(\mathrm{H})$ variety formulas such as: / ?al-baqa:?uli-lla:h/ (Lit. Allah is the Everlasting), and / عaZZama-lla:hu ?azrak/ (Lit. May Allah grant you a greater requital).Cultural meanings relating to such contexts seem to be embedded in these constructions and they are recalled in relevant contexts such as those above. A situation of such type may manifest itself in the following exchange:

A: / عaZZama-lla:hu ?azrak/

( May Allah grant you a greater requital.)

B: / yafara- 1la:hu dambak /

( May Allah forgive your sins.)

ELLS Vol. N No.I

(380)

December 2016 
[ Live conversation]

\subsection{The "eat"-type verbs and the definite article}

The definite article selection in EA seems to be a property of individual verbs, but are there any co-occurrence restrictions? For example, the verb /yihibb/ (to like ) as in: ( baHibb -afrab ?ahwah / ( I like to drink coffee ) and بحب القهوه / baHibb -il-?ahwah / ( I like the coffee ). There is also some sort of collocational relationship between such verbs and their objects. Although Egyptians normally speak of /?ahwah/ (coffee) as a drink using the indefinite form, as in: تثرب قهوه معايا/ tifrab ?ahwa -mعa:yah / (Would you like to have some coffee with me?); and تشرباب / شاى وللا قهوه tifrab fa:y walla ?ahwah / ( Would you like to drink tea or coffee? ), investigation of the eat-type verbs, as used with definite nouns in EA, illustrates the close relationship between them as linguistic units and the sociocultural frame in which they are used. Co-occurrence restrictions between the definite article and the post-verbal noun as used in the eat-type verbs is fairly repetitive and even conventionalized. For instance, the statement:

الفضلو ا نشرب القهوه فى الصالون IitfaDDalu nifrab- 1-?ahwa fiSSalo:n / [TV serial]

( Lit. Let's have the coffee in the sitting room),

said by a host / hostess to his/her guests, can be contrasted with بلا نشرب قهوه / yalla nifrab ?ahwah / (Lit. Let's have some coffee) with a partitive article before the object, said by somebody inviting another. In the first utterance, where the post-verbal noun occurs with the definite article, it can be inferred that it occurs in ritual settings /occasions in which coffee/tea is normally served as a complementary part of lunch /dinner invitations, i.e. the setting, in this case, seems responsible for determining the selection of the definite / 
The Interface between Linguistic Units and Socio-cultural Frames in Egyptian Arabic: A Cognitive Diglossic Perspective

partitive article. In similar situations, where coffee/tea is served at regular times, the definite article is used, as in the following exchange:

Husband: ! القهوه يا لدا / ?il-?ahwa ya nada / [TV serial]

( Lit.The coffee, Nada.)

Wife: حالا يا نبيل، هانطب المواعين واعملك القهوه /Ha:lan ya nabi:1 hafaTTab

il-mawari:n w-aعmil-lak-il-?ahwa/

( A minute, Nabil. I'll wash up and make the coffee for you.)

\subsection{Meals}

\{ نتقابل بعد الفطار \}

/ nit?a:bil ba $\varepsilon d$ - il-fiTa:r /

[ Live conversation]

meet $1^{\text {st }}$ pers.pl. after breakfast

( Let's meet after breakfast)

In EA, names of meals: فطار /fiTa:r/ (breakfast), /yada/ (lunch), and /عa/a/ (dinner) / are syntactically influenced by the socio-cultural settings in which they are used. In a socioreligious setting, namely, during the fasting month of Ramadan, Muslims are supposed to take two meals, one at sunset and another immediately before daybreak. The former is called /?ifTa:r/ (breakfast), and the latter is called /suHu:r/ (a light meal before daybreak). These two meals are employed with the definite article /?il-/(the) when referred to as part of the religious rituals of the holy month of Ramadan, as in:

\{ أنا معزوم ع الفطار بكره

/ ?ana ma $\varepsilon z u: m \quad \varepsilon$-al-fiTa:r rive conve




\section{I}

I invited psv. to breakfast-def. tomorrow

( I'm invited to iftar \{breakfast\} tomorrow.)

As in the above utterance, the name of the meal appears in the definite form when reference is made to it while being prepared or ordered on the phone at their regular times: / gahhizti -1- fiTa:r / ( Lit. Have you prepared the breakfast?) and /?aTlub-l-yada dilwa?ti / (Lit. Shall I order the lunch now?)

On the other hand, the indefinite or partitive article can be used with names of meals outside their regular times as in: / ?ana ha-beat-aftiri -fTa:r/ ( Lit. I'm going to send someone to buy some breakfast.), or / ?aTlub liku $\varepsilon a$ a/ (Lit. Shall I order some dinner for you?)

\subsection{Ritual Dishes}

Some classical Egyptian dishes are culturally recognized, and speakers of EA usually refer to them in the definite form. Such dishes are traditionally related to some religiocultural events, and they include كعك العيد / kaعk-il-عi:d / (

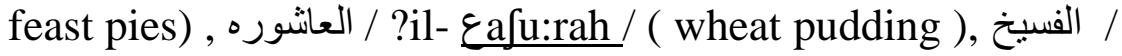
?il-fisi:x / (salted fish), and الفتأ / ? ? الفته / il-fattah / ( An Egyptian dish made of bread crumbs, rice, meat soup and dressed with thick garlic- tomato sauce). For example:

/ ha- tiftiri -1- kaعk -mne:n -issana: -di: /

( Lit. Where will you buy this year's feast pies?)

[ Live conversation]

\subsection{Benefactive /-lak / ( for you)}

One remarkable linguistic feature of EA, which is considered as language-specific, is illustrated in the following exchange: 
The Interface between Linguistic Units and Socio-cultural Frames in Egyptian Arabic: A Cognitive Diglossic Perspective

A husband returns home after a long hectic day complaining to his wife of a severe headache. His wife advises him to take something for his headache and to get some sleep.

Wife: / wiffak -aSfar fi:k ?e:h /(You look pale. What' the matter?)

Husband: / Suda:ع fidi:d / ( I have a bad headache.)

Wife: / xud-lak Ha:ga li-SSuDa:ع w-na:m-lak Juwayyah / (Take [for you] something for the headache, and sleep [for you] for a while.)

\subsection{Prepositional Phrases}

$$
\text { a- }\{\text { بالهنا والثفا \} }
$$

[ Live conversation]

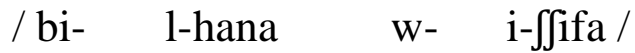

with happiness-def. and recovery-def. (Enjoy it !)

( Lit. with happiness and recovery)

This (L) variety expression is a prepositional phrase. It is peculiar to the Egyptian culture, and it can be used before, during and after meals as a wish for someone to enjoy his meal. In the following exchange, a mother-in-law wishes her son-in-law an enjoyable meal when he praised her cooking. A: / ?il- bamya lazi:za ?awi tislam ?i:dik / [ Live conversation]

okra-def. delicious very save hand-poss. $2^{\text {nd }}$ pers.

( Lit. The okra is so delicious, well done.)

B: / bi -1-hana w- i-fjifa / with happiness-def. and recovery-def. ( Lit. Enjoy your meal )

b- $\{$ على جثى \} \}

[ Live conversation]

/ Eala

gussiti /

ELLS Vol.x No.I

(384)

December 2016 
over dead body-pos. $1^{\text {st }}$ pers.

( Lit. On my dead body )

This (L) variety prepositional phrase is used in situations involving some sort of challenge between two opponents. This expression is culturally recognized in Egypt and perhaps in other Arabic cultures.

c- $\{$ بسم اله الرحمن الرحيم $\}$

[ Live

conversation]

/ bismi- i-lla:hi -rraHma:ni -rraHi:m /

in name-def. Allah-poss. gracious-def. merciful-def.

( In the Name of Allah, the Most Gracious, the Most Merciful )

This $(\mathrm{H})$ variety utterance (borrowed from the Glorious Qur'an) has a very special function in that it can be used, first before reading or reciting the Glorious Qur'an, second, Muslims find blessings in using it before having meals, and thirdly, they use it before embarking on any work or activity.

\section{Proverbs}

\subsection{Imperative Constructions}

a. \{دَّارى على شمعتلك تِقيد

[ Live conversation]

/ da:ri Eala Jameit -ak ti?i:d / cover-imp. on candle.poss. $2^{\text {nd }}$.pers. and it will light up

( Lit. Don't wear your heart on your sleeve. )

This popular proverb is classified as (L)variety in EA. It has the force of advice, and it is used in situations advising the listener to protect his/her future plans by not allowing others to see or know what they are planning. An Egyptian cultural frame recommends that when one has an intention to take an important step, one should be careful not to let others know 
The Interface between Linguistic Units and Socio-cultural Frames in Egyptian Arabic: A Cognitive Diglossic Perspective

what one intends to do, lest something may go wrong. Here, the speaker uses the above utterance in a situation involving somebody speaking openly of some serious plan he/she intends to do. S/he advises the recipient to work in private if s/he wants everything to go right. The $(\mathrm{H})$ variety version of the above saying, which is often used by educated speakers, is:

"إستعينو ا على قضاء حوائجكم بالكتمان..."

[Prophetic tradition ]

?istaعi:n-u عala: qaDa:?i Hawa:?i3-i-kum bi-l-kitma:n /

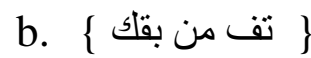

[ Live conversation]

/ tiff min bu??ak /

spit from mouth-poss. $2^{\text {nd }}$ pers.

\{Lit. Spit out your saliva\} (Don't say that!)

This (L) variety expression occurs in a socio-cultural frame involving a participant talking of some impending news/ event which is not favourable to the other participant who hastens to express his dismay and rejection by commenting on the speaker's remark saying: / tiff min bu??ak / ( don't say that!). This expression is common in EA, and is used in such situations to counteract bad luck and misfortune.

c. $\{$ نمسك الخشب \}

[ Live conversation]

/ nimsik -il-xafab / ( Lit: Let's touch wood ) \{ Touch wood !\}

This (L) variety idiom is fairly common among peers and intimates in the Egyptian culture, and it is used on occasions involving a participant speaking of someone else's good fortune, good qualities, properties or belongings in his/her presence among others. For fear of being taken as having a grudge against or being envious of others, the speaker says 
in the middle of his /her speech: / nimsik -il-xafab /. It is worth noting that the person being talked about may say this idiom jokingly to the speaker as a counterattack to envious eyes. This same meaning is expressed in the (L) variety idiom \{ خمسه و خميسه / xamsa w- xme:sah /, but it is used especially among female peers and intimates. The equivalent $(\mathrm{H})$ variety for the above utterances is the Qur'anic verse:

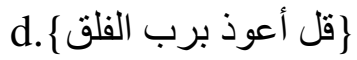

[ Live conversation]

/ qul ?aعu:ðu bi rabb- il- falaq /

( I seek refuge with the Lord of the Dawn).

e.

\{.

اتفضلوا

الله

[ TV serial ]

/ bism- i-llah -tfaDDalu ya-gama:عah /

( Lit: In the name of Allah. Help yourselves, folks )

\{ Help yourselves, please ! \}

This (L) variety expression is common among a fairly large sector of the Egyptian society. It is used as an invitation to guests to start eating, especially when the guests are waiting for the host or hostess to join them. At this moment, the host / hostess invites the guest(s) to help himself/themselves, i.e. they do not have to wait.

\subsection{Declarative Constructions}
a.
فوائد
قوم
عند
قوم
مصائب
[ arabiCorpus ]

/ maSa:?ibu qawmin عinda qawmin fawa:?idu/

( Lit. One man's meat is another man's poison)

This saying is classified as $\mathrm{H}$ variety ( MSA) used by EA speakers, educated and non-educated alike, in situations involving a misfortune or an unfavourable happening which is viewed within the same situation as beneficial to another 
The Interface between Linguistic Units and Socio-cultural Frames in Egyptian Arabic: A Cognitive Diglossic Perspective

person. Here, the context of this situation recalls in the mind of the speaker what is often said in commenting on similar repetitive occasions.

b. \{خيرُ البرّ" عاجلهِ

[ Live conversation]

/ xayru-l-birri- عa:3ilihi /

( Lit. The most charitable deed is the one done instantaneously)

( The sooner, the better. )

This wise saying is classified as $\mathrm{H}$ variety ( MSA) used by EA speakers in situations where a speaker has promised to perform a certain act at some future time, and in the meantime the listener is willing to have this promise fulfilled earlier. Here, the listener uses the utterance: / xayru-lbirriEa:3ilihi / ( the sooner, the better), to express a conventionalized idea in the Arabic Islamic culture, as well as in many other cultures.

c. $\{$ حماتك بتحبك $\}$

/ Hama:tak

[ Live conversation]

mother-in-law $2^{\text {nd }}$.pers.poss.

bitHibbak /

( Lit.Your mother-in-law likes you)

This L variety expression occurs during meal times when family members are having a meal and a relative or a friend arrives, often, unexpectedly. At this moment, one, or more of the family members, invites the newcomer, who feels embarrassed to arrive at an inappropriate time, to help himself/herself and share their meal using the conventionalized expression: / Hama:tak bitHibbak / meaning that the guest has arrived at the most appropriate time, and that he is most welcome to eat with them.

d.

خَدَعوك [ arabiCorpus ] 
$3^{\text {rd }}$ pers.deceive-pst. $2^{\text {nd }}$ pers. and said- $3^{\text {rd }}$ pers.

( Lit. They deceived you by this saying ... )

This saying is classified as H-Variety (MSA), used by educated speakers in situations when a participant wants to comment on another's unconvincing argument. Here, the speaker expresses his/her disagreement with, or even rejection of the other participant's statement, and that $\mathrm{s} / \mathrm{he}$ should not have been taken in by such words, as there are many things which may be blindly accepted as part of the culture, though, in fact, such things do not exist at all.

e. $\{$ وَعَد الحُر دين عَليه

/ ward -i-l-Hurri- de:n عale:h /

promise-poss. nobleman debt on him

( Lit: A nobleman's promise is a debt he has to fulfill.)

This (L) variety saying is used in a setting in which one of the participants is reminding another of a previous promise he has taken on himself to fulfill. The two participants had a deal in which one participant had agreed to do a certain act, for which the second participant would adhere to an agreed upon commitment to the first participant, and once the first participant carries out his role, he reminds the second participant of his commitment by using the above conventionalized saying which is often repetitive in such situations.

f.

[arabiCorpus ]
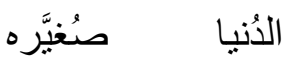

\}

/ ?iddunya Suyayyarah /

world-def. small

( It's a small world!)

This (L) variety expression is used in the Egyptian culture in situations where two people, who are supposed to have known each other in the past, meet unexpectedly after 
The Interface between Linguistic Units and Socio-cultural Frames in Egyptian Arabic: A Cognitive Diglossic Perspective

parting for a long period of time. For example, participants (A) and (B) meet accidentally at an international conference. They remember each other and start a small talk during which participant (A) says: \{ الأنيا صُغَيَّره (It's a small world), to which the other participant replies: / Ha?i:?i / (That's true). The above utterance is commonly employed in typical situations in EA.

g.

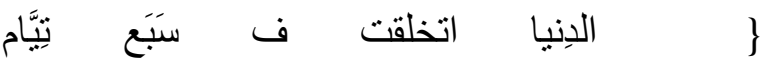

[ TV serial ]

/ ?i-ddinya -itxala?it fi- sabae -tiyya:m /

world-def. created-psv. in seven days

( Lit: The world was created in seven days.) \{ Rome was not built in a day.

This folk proverb is commonly used in contexts involving an impatient participant pushing another to perform a given act, while the other participant sees that there is still plenty of time, and that there is no need for haste, if that job is to be done properly. This situation recalls in the mind of the speaker a well-established proverb in the Egyptian culture expressing the whole situation.

h. $\quad$ \{ كافر

[ Live conversation]

/ ?il- gu:ع ka:fir /

hunger-def. atheist

( Lit: Hunger has no religion), \{ I could eat a horse / I'm starving \}.

This (L) variety saying is common in the Egyptian culture, and it is used in such situations as when a husband returns home feeling hungry to find that lunch is not ready as usual. His wife asks him to wait for some time, but he goes to the kitchen to find something to eat telling his wife that he is so hungry that he cannot wait any more. In the middle of eating 
he says: \{ الجوع كافر \}, (Lit: Hunger has no religion), \{ I could eat a horse $\}$.

i. $\quad\left\{\begin{array}{l}\text { ع } \\ \text { \} }\end{array}\right.$

/ عe:ni bi-triff /

[ Live conversation]

eye-poss. $1^{\text {st }}$ pers. flickers

( Lit: My eye is flickering )

\{ I have a vague feeling \}

This is a (L) variety idiom used in a situation in which a person has a mysterious presentiment that something unpleasant is going to happen. This vague feeling is often accompanied with an involuntary movement of the person's eyelids.

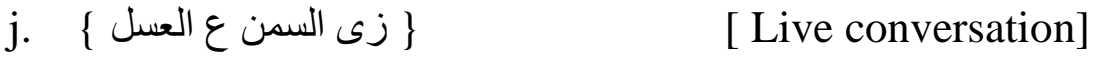

/ zayy- i-ssamn $\varepsilon a-$ l-عasal /

like butter-def. on honey-def.

( Lit: Like butter mixed with honey), \{Like two lovebirds

This (L) variety proverb is used in a setting where a participant is comparing the relationship between two intimate friends to a delicious dish of honey mixed with butter. The setting for this proverb involves two participants discussing the relationship between two friends who have lately on bad terms. One of the participants, who has recently seen them together somewhere talking and laughing, has another opinion that they have become more than just close friends.

A: / nu:ra -w- samar lissa mitxaSmi:n /

( Are Nora and Samar still on bad terms?)

B: / la: du:1 ba?u zayy- i-ssamn عa-l-عasal /

( No, they have become like two lovebirds.)

The previous analysis might provide some insight into the inextricable relationship holding between culture and language. It aimed to argue, by means of examples from EA, against the Sapir-Whorf hypothesis, that the socio- 
The Interface between Linguistic Units and Socio-cultural Frames in Egyptian Arabic: A Cognitive Diglossic Perspective

cultural factors are to a great extent responsible for the grammatical and semantic variation resulting from the variation in socio-cultural contexts, and hence they can strongly influence individuals' communicative performance in relevant contexts in the Egyptian society. Additionally, it has been argued that culture embraces language, and that culture and thought are the real shapers of language.

\section{Conclusion}

This research set out with the proposal that there is a kind of symbiotic relationship holding between language and culture and that one cannot exist without the other. The major hypothesis of the research has been centered on the argument against the Sapir-Whorf hypothesis to show that the structure of cultural knowledge has a strong influence on the organization of the linguistic structure. Investigation of the EA data has shown that contextual factors are responsible for the variation in the structure of linguistic units, and that every linguistic unit, be it a word, phrase, or clause, which is used in a social interactive event, seems to be organized around a particular context of meaning.

The research findings indicate that socio-cultural input plays a crucial role in determining the speaker's linguistic output, since languages exhibit a fairly high degree of sensitivity to socio-cultural frames. This might account for the fact that grammatical constructions are laden with meanings which are prevalent in the collective reservoir of societies. The research has also touched upon the notion that the speaker's recognition of the symbolized value in a certain linguistic utterance serves in conceptualizing the meaning which can help him/her to select the relevant construction from among a range of related ones. Moreover, 
knowledge of the cultural meanings, ideas and concepts, which are embedded in linguistic structures, is important to non-natives, as this knowledge provides speakers of other cultures with more effective tools to communicate with representatives of this culture.

This overview of the mutually dependent relationship between language and culture, though far from being exhaustive, aimed to be selective in providing some representative areas where linguistic categories exhibit sensitivity to certain socio-cultural frames, and how language and culture markedly overlap in varying and relative degrees. This research also draws attention to the areas in which awareness of the socio-cultural frames plays a fairly significant role in determining the structure of the morphosyntax of language.

More significantly, this research still definitely has some gaps to be filled with broader and deeper insights by prospectus researches in the field of language and culture studies. Awareness of the socio-cultural frames will definitely help second, as well as foreign language learners, in selecting the appropriate linguistic structures for the appropriate contexts in order to overcome potential misunderstandings. Last, but by no means least, further research is required to delve more deeply into the relationship between language and culture regarding communicative situations which might lead to misunderstandings and miscommunications in cross-cultural interaction. 
The Interface between Linguistic Units and Socio-cultural Frames in Egyptian Arabic: A Cognitive Diglossic Perspective

\section{Bibliography}

Boas, Franz (1911). The Mind of Primitive Man. The Macmillan Company.

El-Batal, M. ( 2009). A Dictionary of Idioms: Egyptian ArabicEnglish. Cairo: Longman.

Ellis, Nick C. \& Robinson, Peter. (2008). “ Second Language Acquisition and Language Instruction" in Handbook of Cognitive Linguistics and Second Language Acquisition.(ed.) by Peter Robinson and Nick C. Ellis. New York \& London: Routledge.

Enfield, N. J. (2002) 'Ethnosyntax: Introduction', in N. J. Enfield (ed.), Ethnosyntax: Explorations in Grammar and Culture, Oxford: Oxford University Press, pp. 330.

Enfield, N. J. (ed.) (2002) Ethnosyntax: Explorations in Grammar and Culture. Oxford: Oxford University Press.

Ferguson, C. A. (1959). “ Diglossia” in Word, vol.15, pp.325-40.

Geertz, C. (1973). The Interpretation of Cultures: Selected Essays. New York: Basic Books.

Gladkova, Anna. (2014) Ethnosyntax: in The Routledge Handbook of Language and Culture. ch3. pp.3350. Accessed on: 27 Sep 2016. https://www.routledgehandbooks.com/doi/10.432 $4 / 978$ 1315793993.

Goddard, C. \& Wierzbecka, Anna. (1995). "Key words, Culture and Cognition" in Philisophica 55, pp. 37-67.

Goodenough, W. H. (1957). "Cultural Anthropology and Linguistics". In P. L. Garvin (ed.), Report of the Seventh Round Table Meeting on Linguistics and

ELLS Vol.X No.I (394) December 2016


Language Study. Washington, DC: Georgetown University Press.

Halliday, M. A. K. \& Hasan R. (1985) Language, Context, and Text: Aspects of language in a social-semiotic perspective. Oxford: OUP.

Halliday, M.A.K. \& Matthiessen, C. (2004). An Introduction to Functional Grammar $3^{\text {rd }}$ (ed.) London: Arnold.

Hammond, J., Burns, A., Joyce, H., Brosnan, D., \& Gerot, L. (1992). English for social purposes: A handbook for teachers of adult literacy. Sydney: National Centre for English Language Teaching and Research, Macquarie University.

Kramsch, Claire (1998). Language and Culture. In Oxford Introductions to Language Study (ed.) H.G. Widdowson. Oxford: Oxford University Press.

Lakoff, G. (1993). "The contemporary theory of metaphor". In A. Ortony (Ed.), Metaphor and Thought (2nd ed.). Cambridge: Cambridge University Press. pp.202251.

Langacker, Ronald W. (1994). "Culture, Cognition, and Grammar". In Martin Pütz (ed.), Language, Contact and Conflict. Amsterdam: John Benjamins, pp.25-53.

Malinowski, B. (1922). Argonauts of the Western Pacific: An account of native enterprise and adventure in the Archipelagoes of Melanesian New Guinea. London: Routledge and Kegan Paul (Enhanced Edition reissued Long Grove, IL: Waveland Press, 2013). 
The Interface between Linguistic Units and Socio-cultural Frames in Egyptian Arabic: A Cognitive Diglossic Perspective

Malinowski, B. (1923). "The problem of meaning in primitive societies" in The Meaning of Meaning. By C.K.Ogden and I.A. Richards. New York: Harcourt, Brace \& World, Inc.

McDaniel, E. R. Samovar, L. A. \& Porter, R. E. (2012) “ Using intercultural communication: the building blocks" in

Samovar, L. A., Porter, R. E., \& McDaniel, E. R. Intercultural Communication: A Reader. Boston: Wadsworth Cengage.

Parkinson, Dilworth. http://arabicorpus.byu.edu

Pinker, Steven. (1995) The Language Instinct. New York: Harper Perennial.

Romaine, S. (1999). Communicating Gender. Mahwah, NJ: Lawrence Erlbaum.

Ryding, Karin C. (2005). A Reference Grammar of Modern Standard

Arabic. Cambridge: CUP.

Sapir, E. (1929). "The Status of Linguistics as a Science". Language, 5, pp. 207-14.

Sapir, E. (1949) Selected Writings of Edward Sapir in Language, Culture and Personality, (ed.) D. Mandelbaum, Berkeley, CA: University of California Press

Sir Edward Burnett Tylor. (2010). In Encyclopadia Britannica.

Retrieved April 6, 2010, from Encyclopædia

Britannica

Online: http://www.britannica.com/EBchecked/ topic/611503/Sir-Edward-Burnett-Tylor.

Tyler, A. (2008). " Cognitive Linguistics and Second language instruction". In Peter Robinson \& Nick C. Ellis (Eds.), Handbook of cognitive linguistics and 
second language acquisition. New York, NY: Routledge. pp. 456-488.

---------. (2012). Cognitive Linguistics and Second language Learning: Theoretical Basics and Experimental Evidence. New York \& London: Routledge.

Wardhaugh, Ronald. (2006) An Introduction to Sociolinguistics. $\left(5^{\text {th }}\right.$ ed.) Blackwell Books in Linguistics. Oxford: Blackwell Publishing Ltd.

Whorf, Benjamin Lee.(1956) Language, Thought and Reality: Selected Writings of Benjamin Lee Whorf, ed. by: John B. Carroll. New York; London: MIT Press. Wierzbicka, Anna. (1979). "Ethno-syntax and the philosophy of grammar". Studies in Language,3.3: pp. 313-83.

(1992). Semantics, Culture and cognition: Universal human concepts in culture-specific configurations. Oxford \& New York: Oxford University Press. 
The Interface between Linguistic Units and Socio-cultural Frames in Egyptian Arabic: A Cognitive Diglossic Perspective

\section{Appendices \\ (1) Phonemic Conventions for Reading Transcribed Arabic Forms}

\section{Consonants}

/ b/ Voiced bilabial plosive, as in / be:t / (house)

/ d/ Voiced denti-alveolar plosive, non-emphatic, as in, / de:1 / (tail)

/ f / Voiceless labio-dental fricative, as in, / fe:n / ( where )

/g / Voiced velar plosive, as in, / gidi:d / ( new )

/ 3 / Voiced palato-alveolar fricative, as in, / be:3 / ( beige )

/ h/ Glottal fricative, as in, / huwwa / (he )

/ H / Voiceless pharyngeal fricative, as in, / Hilm / (dream )

/q / Voiceless uvular plosive, as in, / ?alqa:hirah / ( Cairo )

/ k / Voiceless velar plosive, as in, / kari:m / (generous )

/ 1 / Voiced denti-alveolar lateral, as in, / le:1/ ( night )

/ $\mathrm{m} /$ Voiced bilabial nasal, as in, / malH / ( salt )

/ n / Voiced denti-alveolar nasal, as in, / nu:r / ( light )

/ r / Voiced alveolar flap, as in, / rigl / ( leg )

/ s / Voiceless alveolar fricative non- emphatic sibilant, as in, / samak /

(fish)

/ $/$ / Voiceless palato-alveolar fricative, as in, / Jams / ( sun )

/ t / Voiceless denti-alveolar plosive non- emphatic, as in, / ti:n $/$ (figs )

/ w / Voiced labio-velar semi-vowel , as in, / walad / ( boy )

/ $\mathrm{x} /$ Voiceless uvular fricative, as in, / xo:x / ( peaches)

/ y / Voiced palatal semi -vowel, as in, / yo:m / ( day )

/ z / Voiced alveolar fricative, non-emphatic sibilant, as in, / ze:t $/$ (oil)

/ ? / Glottal plosive, as in, / ?alam / ( pen )

/と/ Voiced pharyngeal fricative, as in, / عa:li / ( high)

/ y / Voiced uvular fricative, as in, / ỵa:li / (expensive ) 


\section{Emphatic Consonants}

/ S/, / D /, / T /, / Z / are emphatic or velarized consonants. They differ from the non-emphatic / s /, / d /, / t/, / z / in that in the articulation of the emphatic consonants the tongue is laterally expanded so as to fill the mouth.

/ S / as in / So:t / ( sound, voice )

/ D / as in / Dari:f/ ( weak )

/ T / as in / Ta:lib / ( student )

/ Z / as in / Zarf/ (envelope )

\section{Vowels}

/ i / Half-close to close front spread vowel, as in, / fidd / (pull )

/ e / Mid to half-close front spread vowel, as in, / betna / ( our house )

/ a / Front open vowel, as in, / katab / ( he wrote )

/ $\alpha$ / Back open vowel, as in, / Talab / ( request )

/ u / Half-close back to central rounded vowel, as in, / suxn / ( hot )

/ o / Mid to half-close back rounded vowel, as in, / yo:m / ( day)

- Length of vowel is marked by /: /

- Geminated consonants are indicated by doubling the consonant letter.

( Adapted from: Ezzat, A. (1978). Aspects of Language

Study. Beirut:

Beirut Arab University. 
The Interface between Linguistic Units and Socio-cultural Frames in Egyptian Arabic: A Cognitive Diglossic Perspective

(2) List of Abbreviations and Symbols

The following abbreviations and symbols are used throughout this research:

def. definite

EA Egyptian Arabic

fem. feminine

fut. future

$\mathrm{H} \quad$ high variety

imp. imperative

intrns. intransitive verb

Introg. interrogative

L low variety

Lit. literary

MSA modern standard Arabic

mascl. masculine

neg. negative

nom. nominative

NP noun phrase

pers. person

pl. plural

poss. possessive

prep. preposition

psv. passive

sing. singular

SCA Spoken Cairene Arabic

/ a slant indicates optional items

// slants enclose transcribed Arabic forms

(-) a hyphen indicates elision at word boundaries in the transcribed Arabic forms.

ELLS Vol.x No.I (400) December 2016

